Educational Research for Social Change (ERSC)

Volume 8 No. 2, September 2019

pp. $45-60$

ersc.nmmu.ac.za

ISSN: 2221-4070

\title{
Body Mapping as a Critical Pedagogical Tool: Orientating Trainee Psychologists Towards Addressing HIV and AIDS ${ }^{1}$
}

\author{
Kerry Frizelle \\ University of KwaZulu-Natal \\ ORCID: 0000-0001-5706-9269 \\ Frizellek1@ukzn.ac.za
}

\section{Abstract}

This article is the outcome of a classroom-based study that explored whether body mapping, used in a workshop, facilitated a critical analysis of HIV and AIDS amongst a group of trainee psychologists, and orientated them towards addressing some of the factors that drive the epidemic. The article outlines the body mapping exercise and describes how it fits into a broader HIV and AIDS workshop informed by a social justice approach. Key pedagogical insights that emerged about running the body mapping exercise and the workshop as a whole are discussed. The central finding of the study is that body mapping, integrated into a wider social justice workshop, is a useful pedagogical tool that facilitates a critical analysis and orientates students towards addressing HIV and AIDS through their professional practices. However, if this teaching method is to contribute to the kinds of substantial social and systemic change needed to address many of the social issues that drive the epidemic, it needs to be complemented with wider changes in the way in which psychologists are trained.

Keywords: body mapping, HIV and AIDS, critical pedagogy, social justice education, classroom-based study

\section{Copyright: (c) 2019 Frizelle}

This is an open access article distributed under the terms of the Creative Commons Attribution NonCommercial License, which permits unrestricted non-commercial use, distribution, and reproduction in any medium, provided the original author and source are credited.

Please reference as: Frizelle, K. (2019). Body Mapping as a Critical Pedagogical Tool:

Orientating Trainee Psychologists Towards Addressing HIV and AIDS. Educational Research for Social Change, 8(2), 45-60. http://dx.doi.org/10.17159/2221-4070/2019/v8i2a4

\section{Introduction}

In South Africa, as in many parts of the world, there is growing pressure on higher education to produce students who are able to meet the economic demands of the country. Waghid (2007) argued that higher education runs the risk of disregarding important political and social issues that should be its concern, and he argued that a critical university pedagogy is needed. Common to many variations of

\footnotetext{
${ }^{1}$ Ethical clearance number: HSS/0244/013D
} 
critical pedagogy is, firstly, a belief in education as a "moral and political practice" and, secondly, a belief that education should contribute towards building a substantive democracy (Giroux \& Giroux, 2006, p. 21). In South Africa, where the curriculum of higher education has historically (re)produced "deference, chauvinism, xenophobia and other illiberal and undemocratic processes" (Waghid, 2004, p. 283), critical pedagogy is particularly important. Giroux (2001, p. 201) argued for a "citizen education" that cultivates "civic courage," that is, insight into, and the motivation to challenge, wider social forces that constrain democracy.

I am an educator working in an institute of higher education in the discipline of psychology. For more than 10 years, I have been addressing the social issue of HIV and AIDS through my educational practices. Willan (2000) argued that HIV and AIDS is a social issue that has the potential to undermine the democratic project of South Africa. While significant improvements in treatment mean that the number of people in South Africa living with HIV and AIDS has increased, HIV incidence is still relatively high. In 2017, there were 88,000 new infections in the 15-24-years age category (Human Sciences Research Council, HSRC, 2018). The ongoing gender disparity in these new infections is worrying with 22,000 in males, and an alarming 66,000 in females. Similarly, in 2012, in the 20-34-years age category, the highest number of infections was in black African women. In terms of location, people living in urban informal settlements had the highest incidence rates (Shisana et al., 2014). In the words of Fassin (2003), these statistics illustrate that HIV and AIDS in South Africa is largely the "embodiment of inequality" (p. 54). HIV and AIDS "is a social condition" where a number of social factors (like gender, race, and class) lead to a disparity in the risk of infection, in access to treatment, and in the ability to confront the epidemic (Fassin, 2003, p. 55).

Early in the HIV and AIDS epidemic, research and interventions were largely focused on analysing and changing thinking. Researchers, for example, relied on measures of individual knowledge, perceptions, and behaviour to try and explain HIV transmission. This meant that the contexts in which knowledge was received, and sexuality was negotiated, were consistently overlooked (MacPhail \& Campbell, 2001). HIV and AIDS were considered to be the outcome of risky individual behaviour, and this view was embedded in many of the interventions developed to address the rapidly growing epidemic. In 1998, for example, as a trainee psychologist, I was trained to instruct HIV and AIDS counsellors on how to conduct pre- and post-HIV test counselling. We counsellors were trained in behavioural and cognitive methods to change our clients' thoughts-with the expectation that this would, in turn, change their behaviour. What was missing was recognition of the ways in which, for example, class and gender mediated our clients' negotiation of their sexuality. Shortly after entering academia, I volunteered to train trainee psychologists in pre- and post-HIV test counselling. However, my reading of critical psychology, particularly critical health psychology, forced to me to reconsider what I was teaching. Critical health psychology challenges mainstream psychology's tendency to see health as the outcome of individual lifestyle choices. A mainstream perspective leads to victim blaming where people who, for example, are HIV positive, are seen as responsible for their status (Murray, Nelson, Poland, Maticke-Tyndale, \& Ferris, 2004). A critical approach adopts an ecological perspective that recognises the impact of power and social contexts on health (Murray et al., 2004). Having also become increasingly familiar with the ideas of critical pedagogy and, in particular, Freire's (1970/1996) emphasis on a dialogical teaching approach and the development of critical thinking, I realised I also needed to rethink how I was teaching. Informed by these insights, I started to contemplate how I could engage students in a more dialogical, critical analysis of the institutional, social, and individual factors that create the oppressive contexts that constrain how people experience HIV and AIDS (Hackman, 2005). Giroux (2001, pp. 203-204) emphasised that while critical pedagogy should enable students to gain insight into the "structural and ideological forces that influence and restrict their lives," this analysis should not lead to despair and the "inability to dream, imagine or think about a better world"; he argued that critical pedagogy should be "infused with a passion and optimism that speaks to possibilities." It was, therefore, important to create opportunities for students to consider how they 
could, through their future professional practices, address some of the factors they identified during their analysis.

I had recently read about a colleague who used a participatory educational technique called body mapping to encourage critical reflection amongst her media students (Mpofana, 2013). I was not entirely unfamiliar with the technique because I had previously been introduced to it through a book called Long Life: Positive HIV Stories (Morgan \& The Bambanani Women's Group, 2003). This book provided an account of how body mapping was used to visually represent the lived experiences of a group of HIV positive women. Briefly, the exercise involves providing each student with a piece of lifesize paper on which they trace the outline of their bodies. Using paints and crayons or pastels, the students respond to a series of reflective questions by drawing and writing onto their traced bodies. Brett-MacLean (2009) argued that body mapping "offers both a metaphor and means of recognizing the fluid tracings of the personal, social, geographical and emotional experience" (p. 740). MacGregor (2009) similarly argued that body mapping creates an awareness of the social context of HIV and AIDS; she saw it as "tracing the personal and political dimensions of HIV/AIDS" (p. 85). I wondered whether a body mapping exercise would assist my students in better understanding how wider social and political processes impact on how HIV and AIDS is experienced. In this article, I report on the findings of a classroom-based study in which I formally explore the pedagogical value of using body mapping as a teaching method as part of a wider HIV and AIDS workshop informed by a social justice approach.

The remainder of this article is composed of two parts. In the first, I outline the theoretical framework of the intervention and how it informed the design of the HIV and AIDS workshop, and then I describe the body mapping exercise in detail and explain how it fitted into the HIV and AIDS workshop as a whole. The second part of the paper focuses on the methodology of the study, outlines its research questions, and presents the findings of an analysis of reflection papers written by the students at the culmination of the workshop.

\section{Critical Pedagogy and Social Justice Education: Theory and Approach}

Henry Giroux (2001) contended that critical pedagogy is built on the critical theories of the Frankfurt School, citing the various works of theorists including Adorno, Horkheimer, and Marcuse. He argued that the Frankfurt School presented a body of thought that acknowledged the "antagonistic relations between the individual and society" (Giroux, 2001, p. 36). Giroux (2001, p. 31) emphasised the writing of critical theorist Marcuse $(1955,1964)$, who recognised that despite the way in which society constrains human behaviour, human beings can act on and transform society. Foregrounded by critical theory is the importance of critical thinking, which is seen as "a constitutive feature of the struggle for self-emancipation and social change" (Giroux, 2001, p. 8). Applied to education, Giroux (2001, p. 36) argued that critical theory points critical educators "toward a mode of analysis that stresses the breaks, discontinuities, and tensions in history, all of which . . . highlights the centrality of human agency." Critical pedagogy, therefore, emphasises the importance of developing students' ability to critically analyse society. However, Giroux (2001, p. 38) stressed that "human beings not only make history, they also make the constraints; and needless to say, they also unmake them." Thus, the belief in resistance and hope in transformation is fundamental to critical pedagogy.

Paulo Freire (1970/1996) is a key critical pedagogy theorist whose vision of a critical education is seen in his notion of problem-posing education (p. 60); in opposition to banking education that "anesthetises" students, problem-posing education "involves a constant unveiling of society" and strives for "the emergence of consciousness and critical intervention in reality." This critical form of education emphasises a dialogical teaching approach that actively engages students in the learning approach, develops critical thinking, and fosters a belief (hope) in the possibility of transforming the world (Freire, 1970/1996, p. 65). 
A form of critical pedagogy is social justice education (Bell, 2007, p. 2). Bell described the goal of social justice education as enabling students to:

develop the critical analytical tools necessary to understand oppression and their own socialisation within oppressive systems, and to develop a sense of agency and capacity to interrupt and change oppressive patterns of behaviours in themselves and the institutions and communities they are part of. $(2007$, p. 2$)$

Social justice education, therefore, acknowledges both the pervasive and restrictive workings of oppression in society and the ability to change them (Bell, 2007). Hackman (2005) has translated the theory of social justice into a practical approach, and identified five essential components to social justice education:

- Content mastery

- Tools for critical analysis

- Tools for social change

- Tools for personal reflection

- An awareness of multicultural group dynamics. (p. 104)

Hackman (2005) argued that that it is the "combination and interaction" of all five of these components that creates the ideal environment for effective social justice education. Her work provided me with a way of framing my workshop and the location of the body mapping exercise within it. Body mapping is a fun, creative, and evocative method-but its main function is not entertainment and it, therefore, needs to be used strategically with other teaching methods to ensure that it facilitates learning. In the next section I provide a brief description of the workshop, the body mapping exercise, and illustrate how it is located in a workshop informed by a social justice approach (I identify which component is relevant in parentheses).

\section{The Workshop and Body Mapping Exercise}

I adapted the body mapping exercise described by Morgan and The Bambanani Women's Group (2003) and Mpofana (2013).

\section{Day One}

\section{Part One: Introductory activities.}

The workshop was run with a group of nine trainee psychologists, registered for their master's degree in psychology. The group was made up of eight female students and one male student. Five students were white, three black, and one Indian. While South Africa strives to be non-racial, the classification of races is still recognised in an attempt to address many of the inequalities of the past. In addition, the analysis will show that the social construct of race informed how these students viewed and experienced HIV and AIDS. Each student was provided with a piece of body length paper. I provided an outline of the workshop and the technique of body mapping, and emphasised the confidential context in which it would be facilitated. It is essential to create a safe space for this exercise. Students then took turns to trace the outline of each other's bodies onto the paper (see Image 1). Time was given for them to use paints to give colour to their outlines. 


\section{Image 1}

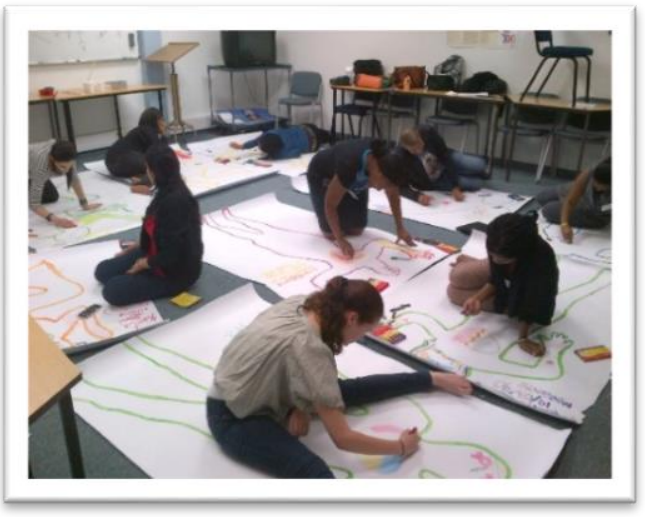

\section{Part Two: The head.}

Students were asked to draw into the space of the head, the first image or symbol that came to mind when they heard the word "AIDS." Once finished, I asked the students to walk around and observe their colleagues' drawings and then discuss what the images revealed collectively. Through analysing their own symbols and those around them, I wanted them to become aware of how people have internalised social representations of HIV and AIDS (Components 1, 2, \& 4). During the discussion, I was able to link their personal experiences to relevant information (Component 1 ). For example, one student drew a red balloon (see Image 2 ) in her head, and shared that it represented an experience when she had attended a friend's funeral. Due to the magnitude of AIDS-related deaths at the time, the family had flown a red balloon at the site of his grave to point mourners in the right direction. This led to a discussion of the way in which the development of, and increased access to, ARVs has led to a decrease in the number of deaths and the implications of this for families and friends. As a class, we also discussed the importance of exploring clients' internalised representations of HIV and AIDS that have been found to impact on how they experience themselves or others as being HIV positive (Rohleder, 2016). In this way, factual information emerged in relation to the students' personal experiences-a dialogical teaching strategy (Freire, 1970/1996). This strategy also applied to the other stages of the body mapping exercise.

\section{Image 2}

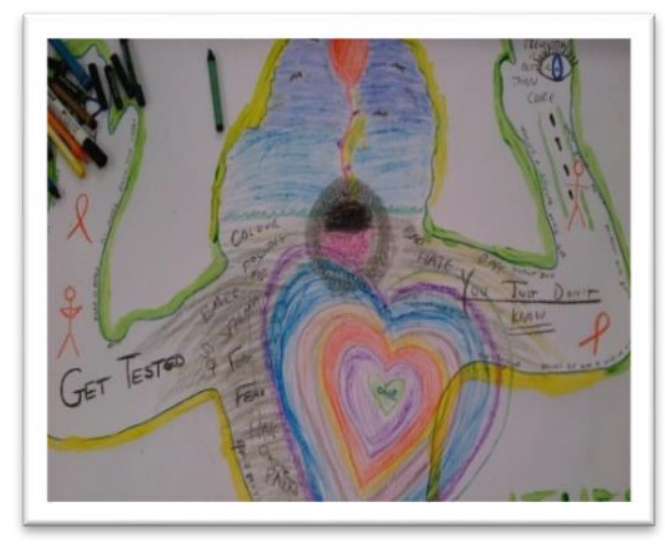

\section{Part Three: The hands.}

I asked the students to see their hands as metaphors for their everyday communities and as embodying these communities' beliefs about HIV and AIDS and, more specifically, how these wider beliefs may have influenced the meanings that they themselves have attached to the epidemic (Components $2 \&$ 
4). The students were asked to write these beliefs into the hands (see Image 3 ). They were then given the opportunity to discuss these beliefs collectively (Component 4).

\section{Image 3}

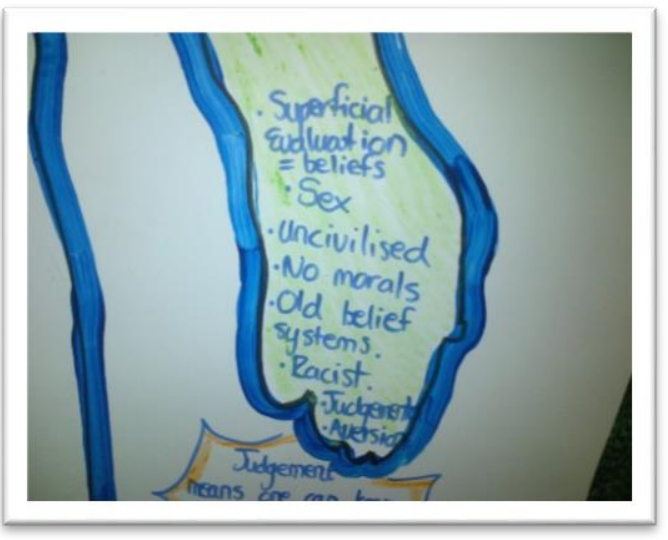

Part Four: The heart.

Next, I asked the students to focus on the chest area of their body maps, and to think about the heart as a metaphor that represents their emotional responses to the epidemic. I asked them to express these emotions with colour in the chest area (Image 4) and write down any memory they had of a direct experience with HIV and AIDS (Component 4). Opportunity was again given for a group discussion. Day One of the workshop ended after Part Four was completed.

\section{Image 4}

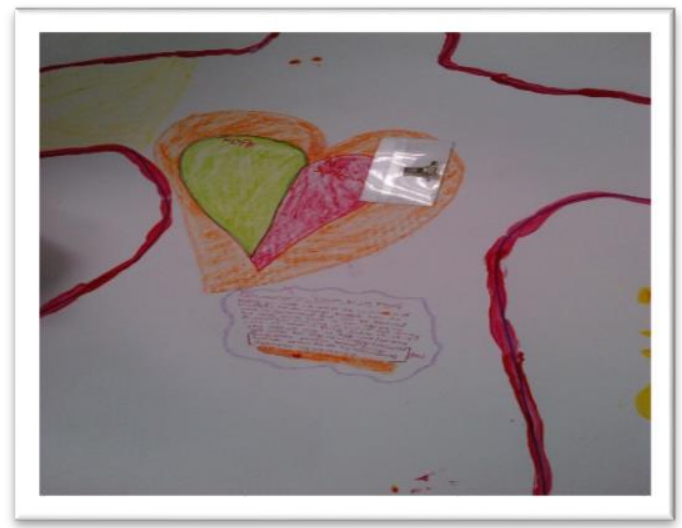

\section{Day Two and Day Three}

Presentation and discussions.

The first of the five components identified by Hackman (2005) acknowledges that central to any social justice education is relevant information. Content mastery (Component 1 ) was central to all of the activities incorporated into the workshop. Day Two and Day Three used more formal presentations to facilitate discussions around the history of HIV and AIDS locally, nationally, and internationally, central facts and information about HIV and AIDS, and the range of psycho-social issues related to HIV and AIDS. 
Hackman (2005) emphasised that social justice educators need to also be vigilant not to "reproduce dominant, hegemonic ideologies" through the content they teach (Component 1). It is, therefore, important for educators to ensure that they include a thorough historical and political overview of the information they include (Hackman, 2005). Hackman (2005, p. 107) suggested that educators need to reflect (Component 4) on their own social position and the impact this can have on what they teach; through critical self-reflection, an educator can "extricate oneself from the trappings of," for example, "invisible privilege." I am a white South African and my response to HIV and AIDS has a history that has needed to be reflexively engaged with on an ongoing basis. In the past, for example, I have included information on how former President Mbeki contributed to a number of avoidable HIV infections through his AIDS denialism. Over time, I have recognised how my position as a white person had led me to foreground Mbeki while overlooking how leaders during colonialism and apartheid contributed to the unfolding of a devastating epidemic in South Africa (Phatlane, 2003) and, therefore, now ensure that I include this information in my workshops too.

Hackman (2005) emphasised that social justice educators also have to be aware of the many identities that present themselves in the learning space (Component 5). The students I teach are mostly from South Africa and continue to live in a context characterised by the inequality and oppression that are a legacy of apartheid. There are students from all the socially constructed racial categories that were entrenched during the years of apartheid. It is not unusual for students to produce problematic statements, for example, around race, when trying to understand the epidemic in South Africa. During the workshop presentations, for instance, we critically analyse the statistics around HIV prevalence (Components $1 \& 2$ ). Evidence from surveys suggests that more black Africans are infected than any other racially defined group in the country. The latest South African national HIV prevalence study reported that HIV prevalence among black Africans is 16.6 per cent, while it is 5.3 per cent amongst coloured people, 1.1 percent amongst whites and 0.8 percent amongst Indians (HSRC, 2018). In a country where the sexuality of both black men and women has been historically denigrated, it is extremely important not to contribute towards a (re)production of problematic representations of a hypersexual black male sexuality and passive female sexuality (Lewis, 2011) and so a careful and critical engagement with these statistics is essential. As Hackman (2005) argued, the aim is not to avoid such difficult discussions but, rather, to facilitate them in constructive ways. This requires "strategic empathy" - a willingness to "empathise with the troubled knowledge students carry with them, even when this troubled knowledge is disturbing to other students and the teacher" (Lindquist, 2004, as cited in Zembylas, 2015, p. 172). If lecturers deal with these responses with strategic empathy they have a better chance of assisting students to challenge these views (Zembylas, 2015).

An important part of content mastery (Component 1 ) is providing students with tools to critically analyse and, therefore, "understand the micro-level implications of macro issues" (Component 2; Hackman, 2005, p. 105). One way of doing this is to provide students with a theoretical framework through which they can process the information they are engaging with. When presenting information on the prevalence and incidence of HIV and AIDS, for example, I introduce the students to parts of activity theory. In sum, activity theory draws attention to the "communal and social character of action" by arguing that human behaviours are always mediated by wider interacting subsystems (Kelly, Parker, \& Lewis, 2001, p. 251). This theory essentially challenges decontexualised explanations of human behaviour. This theoretical framework is particularly useful as a tool for critically analysing health-related behaviours and, in the analysis section, I discuss how the theory was used by a participant to reframe a personal experience. 


\section{Day Three}

Reflection paper guidelines and body mapping Part Five: The feet.

On the second half of Day Three, the students were given some broad guidelines on how to write a reflective paper. They were asked to reflect on the entire process of the workshop, identify and discuss key learning moments, and indicate how they are likely to respond to HIV and AIDS as a psychologist based on what they have learned (Component 4). The students were then asked to return to their body maps and write into their feet their plans for future action as practising psychologists. This part of the body mapping exercise (Component 3) orientates them towards action and fosters a sense of possibility rather than the despair and cynicism that can happen when identifying wider social factors that drive the epidemic (Hackman, 2005). The students completed the reflection paper in their own time.

\section{Classroom-Based Research and Methodology}

\section{Background, Aim, and Questions}

When I read the students' reflection papers, I was excited to see how many of them made specific reference to the body mapping experience and the learning that this had enabled. Classroom-based research recognises that many educators engage in informal reflection on their practices, but that there is a need to "deliberate more explicitly about practice" (Wilson, 2012, p. 1). From my initial reading of the reflection papers, I felt that the body mapping exercise had been an effective learning experience. I decided to explore this assumption through a formal analysis of the students' reflection papers.

The aim of this research, in line with the main aims of classroom-based research (Kostoulas \& Lammerer, 2015), was to improve my own teaching practices and provide other educators working in the context of HIV and AIDS with data-based evidence on the usefulness of the body mapping exercise and the HIV and AIDS workshop, more broadly.

I aimed to answer three research questions though this small-scale, qualitative classroom-based study:

- Did the workshop and the body mapping exercise facilitate a critical reading of the HIV and AIDS epidemic?

- Did the workshop and the body mapping exercise orientate the students towards action through their future professional practices?

- What pedagogical insights into running the workshop and body mapping exercise emerge from an analysis of students' reflection papers?

\section{Data Source, Collection, and Analysis}

The data for this study was student generated, and consisted of the students' reflection papers. The study is part of a larger study that has received ethical clearance from the University of KwaZulu-Natal's research ethics committee. After I had read the papers, I returned them to the students with a consent letter attached, which explained that I wished to use their reflection papers to reflect on my teaching practices. I explained that they were not obligated to let me use their papers, and that if they consented they were free to highlight areas they did not want me to use. I also explained that they could withdraw from the process at any point without any negative consequences. In order not to put face-to-face pressure on them, I invited them to leave their papers and their signed consent letters with the administrator if they consented. The students were also assured that they would remain 
anonymous in the write-up of the results. All nine of the students who participated in the workshop gave me their consent to use their papers for research purposes.

Thematic analysis was used to analyse the reflection papers. The initial process of analysis occurred when I first read the students' reflection papers. I then did a second reading of the papers, with my first research question framing my analysis. I was vigilant for when students made reference to the body mapping exercise, and any indication that it had enabled a critical analysis of the HIV and AIDS epidemic. I then proceeded with a third reading, where I was vigilant for when students made reference to their future plans to address HIV and AIDS as professional psychologists. During the fourth reading, I looked for any pedagogical insights I could gain into the process of facilitating the body mapping exercise and the workshop, more broadly. The discussion of the data was informed by my broader reading around critical pedagogy and social justice education. While all of the students' papers were included in the analysis, due to space constraints the findings will include data extracts from five of the students (Participants A through to $E$ ).

\section{A Critical Reading of HIV and AIDS}

Insights into socially mediated beliefs and experiences relating to HIV and AIDS.

Participant A described how the body mapping exercise enabled her to understand her own positioning in relation to HIV and AIDS. She described leaving the first day of the workshop with a headache and put this down to the "emotional intensity" of hearing her black peers' personal experiences. She had the following insights:

Ironically, my greatest discomfort was in realising that I did not have a personal experience of HIV and AIDS to share. . . I found myself asking the following question: Had my privileged, white, middle-class upbringing afforded me the opportunity to keep far away and be protected?... The answer I arrived at was a yes.

The following extract demonstrates how the same participant began to challenge her problematic assumption that HIV infections are primarily the result of experiences of violation, rather than everyday sexual activities, and how this process of othering allowed her to insulate herself from any personal perception of risk.

In my mind, HIV and AIDS was only... the consequence of violation, violence and assault and I found myself part of the hundreds of people who believe that "it will never happen to me."

Participant $\mathrm{C}$, also a white student, reflected on the dilemma she felt when she was asked to draw a symbol that represented HIV and AIDS in the head of her body map. The first image that had come to mind was of a rural landscape with African huts. She acknowledged that, as she reflected on this image, she realised with horror that the image implied that HIV and AIDS was "a disease occurring in the black, South African population." As a result, she considered drawing a "more politically correct image" such as an AIDS ribbon, but in the end:

I decided to draw my initial image. . . in order to externalise the evident prejudice my image was embodying, thereby providing the opportunity to address my prejudice. . . . Realising the extent of the prejudice that exists in relation to HIV and AIDS and, most frighteningly, that this prejudice existed within me, made this one of my biggest learning areas. 
During Part Three (the heart) of the body mapping exercise, Participant B, a black student, drew into the chest area a brightly coloured heart (see Image 4). Alongside it, she wrote about a painful personal experience. The following extract highlights how she expressed her anger and confusion in relation to loved ones who had died as a result of what she had perceived as "inaction" in the face of available resources:

The first seminar of the workshop was the worst because it revealed so many things for me. During this day, we were asked to think of HIV and AIDS and write down anything that comes to mind when we think of those words, for me this really brought about discomfort and a lot of emotions because I thought of my loved ones that I have lost because of HIV and AIDS and how those emotions were accompanied with anger. Anger is mentioned, not because I was angry at the virus itself, but angry at them for not taking a stand against the virus and taking the medication that would assist them in getting better. Instead, they decided to suffer alone and not tell anyone what was wrong with them until it was too late. Knowing that the government has made the medication available and there are support groups that are in place to help them cope with this situation came with a lot of confusion as to why they would really choose to suffer like that even though they know that there are services that can help them.

It was only when I read her reflection paper that I was able to appreciate the full extent of what the body mapping process, combined with other aspects of the workshop, had enabled for her. On Day Two, I had introduced the students to the activity systems theory outlined by Kelly et al. (2001, p. 255), which argues that human activities are always mediated by a number of intersecting subsystems "termed 'intentionality,' 'communality' and 'sociality."' To explain this theory, and to model how theory can facilitate critical analysis, I shared how I had come to understand a personal experience using the theory. During my counselling psychology internship, I was part of a group responsible for organising an HIV and AIDS awareness campaign on a university campus. One of the events focused on raising awareness about, and promoting, male condom use. The then minister of health, Nkosazana Dlamini-Zuma, addressed the students and directly promoted condom use; we widely distributed male condoms with relevant information and made sure that condoms were accessible on campus. A few days later, a woman presented at the clinic with injuries from being assaulted after initiating condom use. Using activity systems, I explained to the students that, at the individual level of intentionality, our intervention had clearly motivated this student to initiate condom use with her sexual partner. At the sociality level, a strong message from a powerful person had been communicated and we insured condoms were accessible to students on campus. Something, however, at the communality level had undermined the functioning of the intentionality-sociality system. Initiating condom use in a context where unequal gender norms and hegemonic discourses of masculinity were pervasive and left unchallenged, came at a cost for this student.

The following extract illustrates, powerfully, how using the theory of activity systems enabled Participant B to critically analyse and, therefore, reframe her understanding of her loved ones' decision not to seek treatment:

This model made me realise and understand the reasons behind the resistance of my loved ones in taking medication and rather keeping their sickness to themselves. This is not because the resources were not there but because of their surroundings and their environment which made them react this way. I understand, at a sociality level, there are structures that provide services for HIV and AIDS patients and the treatment is readily available to the general public as well, but because at the communality level the treatment they received from the nurses and the stigma that is attached to the virus they, at the individual level, decided not to go to the clinic or even to the hospital to get the treatment. 
On the first day of the workshop, Participant B had connected with her anger and pain in relation to the death of loved ones through the body mapping activity. On Day Two, activity systems theory had enabled a critical analysis through which her family were no longer positioned as simply passive or irresponsible in a wider context of available resources. She now understood how their ability to act at the individual level had been constrained by wider social factors and that her loved ones' adherence to a life-saving treatment was undermined by a wider system of stigma.

Participant $\mathrm{D}$, a black student, wrote about how the body mapping exercise had brought up memories of his brother's death as a result of AIDS. He gained insight into the way in which the pervasive stigma in his community at the time had resulted in silence around his brother's death and negatively impacted on his ability to grieve:

When a family member, friend, colleague passes away because of AIDS, there tends to be silence around the event. It is kept hush-hush, no one dares talk about it, not dares to ask about ... no one wants to talk about it, it gets ignored, but it never goes away, it haunts you, it keep creeping out and making its presence felt.

The body mapping exercise appears to have facilitated a process of politicisation, a critical process through which social phenomena are placed "within the register of the political and thereby show up the extent to which human psychology is intimately linked to, and in some ways conditioned or limited by, the socio-political and historical forces of its situation" (Hook, 2004, p. 20). In this case, students became aware of how an ideology of race had informed their views and positioned them in particular ways in relation to HIV and AIDS. Participants B and D illustrate insight into the wider context of stigma and discrimination that had severe emotional implications for them.

\section{Pedagogical Insights}

A pedagogy of discomfort.

Participant B described connecting with her anger in relation to the death of her loved ones as the "worst" part of the workshop. She further described this as causing "discomfort." Almost all the students commented on the intense emotions that the body mapping exercise elicited. For example, Participant $D$ described how the exercise led to him sharing, for the first time, his experience of losing his brother to HIV and AIDS:

Let the reader not be disillusioned, it was not easy; it was one of the hardest things I had to do. I thought, "What if my classmates then judge me, what if they judge my late brother, what if they stigmatise me?"

Zembylas (2015, p. 163), a critical pedagogue, argued that difficult and uncomfortable emotions are a necessary part of learning. He, however, questioned whether there are limits to such a pedagogy of discomfort:

If students are essentially "forced" to experience discomfort, pain or suffering as a result of being exposed to "difficult" testimonies, and if they are "pushed" into particular directions in their transformation, do such acts risk doing violence to students? (Zembylas, 2015, p. 170).

Zembylas $(2015$, p. 163) referred to this outcome as "ethical violence." I believe that if there had not been an opportunity for Participant B to process her strong emotional reaction, it would have been a basis for ethical violence. However, the rest of the workshop, and the analytical frame of activity theory 
in particular, enabled her to think through her experience and to reframe it. Participant $D$ described how, despite his initial fears associated with sharing his experience, "I felt heard, I felt listened to, for me that was the healing part ... I felt contained and I felt supported." Participant C, a white student, reflected on how when she was exposed to the stories of some of her black peers whose sociohistorical positioning meant they had had more personal experiences with HIV and AIDS, she had experienced guilt. She wrote the following:

I felt guilty that I had been so privileged to have never had to deal with the virus affecting me or anyone close to me . . I believe this shame and guilt that arose out of my coming into awareness about my prejudice was healthy, however, as it served as a powerful impetus to address my own and others' prejudice.

Importantly, for Participant C, the workshop did not leave her feeling immobilised by her guilt but, rather, led to a commitment to challenge problematic prejudice in herself and those around her.

Walker and Palacios (2016, p. 175) noted that emotive learning is often labelled as "individualistic 'therapeutic pedagogy,' counter to transformational change" and warned that when learning evokes strong feelings like guilt or shame, the experience could turn out to be "pedagogically unproductive" (p. 179). Fortunately, Participants $B$ and $C$ and $D$ were able to work constructively with their emotions. This highlights the importance of dealing with emotional responses both critically and strategically (Zembylas, 2015) by ensuring an ethic of care, and building in opportunities for students to process and understand their emotional reactions.

\section{A pedagogy of hope.}

Hackman (2005, p. 106) emphasised that social justice educators need to avoid the "pitfalls and paralysis, hopelessness, cynicism, and powerlessness" that a critical analysis of oppression can elicit. It was encouraging to note how many students made reference to hope as a result of engaging in the workshop as a whole. Six of the participants made direct reference to hope, and one made indirect reference to it. For example, Participant B described how the workshop as a whole had provided her with a new learning experience that fostered hope rather than fear:

I have learnt and was taught about HIV and AIDS almost throughout my life and some of the methods of teachings that were used did not benefit me in any way because they made me fear. ... Upon finishing this workshop, I feel that there is a sense of hope.

Participant E recounted how, as a result of having attended HIV and AIDS workshops throughout school, she was not very enthusiastic about the prospect of having to attend another workshop, but indicated, indirectly, that this workshop had instilled hope:

I never expected to learn as much as I did, and to come away from the workshop feeling inspired to make a change.

Participant A wrote that, as a result of participating in the workshop, she has developed hope that has motivated her to work in the area of HIV and AIDS:

I have also found a renewed hope and compassion for HIV positive individuals, which has stirred my interest in becoming professionally involved in facing this disease head-on.

Participant $C$ described how she can use the information she gained about antiretrovirals to educate people "to provide them with a sense of hope." 
Zembylas (2015) argued for a pedagogy of critical hope that challenges the belief that nothing can be done to overcome the challenges presented by material conditions. I foster critical hope by, for example, including, alongside a historical analysis of the South African government's failings around treatment, information about how the activism of the Treatment Action Campaign (TAC) led to greater access to treatment (Mac Gregor, 2009). Historical stories of resistance "provide hope as well as evidence that oppressive circumstances can change through efforts of human action" (Bell, 2007, p. 5). The group analysis and discussion of the symbols students drew into their heads also revealed a counter-narrative of hope, challenging a more pervasive historical narrative of despair and pessimism.

\section{Orientation Toward Action}

While all the students identified ways in which they could respond as professionals, the analysis suggests that despite their critical insights into the HIV and AIDS epidemic they were primarily orientated towards individual-level interventions as psychologists working with individual clients. This is evident in Participant A's reflection paper:

I therefore see my role as a professional . . as working with other mental health care workers to improve the mental health of HIV positive people. This includes working towards branding HIV and AIDS as a manageable illness rather than a death sentence, and working within the realm of positive psychology rather than pathology to support HIV positive individuals through their journey.

Participant A did, however, highlight the need to work in collaboration with other health care workers to address the shortage of mental health services and, therefore, committed herself to "be involved in training community health care workers."

Participants $\mathrm{C}$ also made reference to individual-level change in her commitment to challenge prejudice:

The most important role I can play is to shift people's ideas of HIV away from viewing it as a racialised, stereotyped virus that comes with a death sentence, to that of a normalised, universal infection that is treatable and manageable.

While participant $C$ saw herself as primarily challenging individual views, she did indicate that she wished to do this work beyond the confines of individual psychotherapy by running workshops and challenging people in her private and social settings.

Participant $D$ also emphasised the importance of working with families and communities rather than with individual clients. He showed insight into the need for changes in wider systems:

Individuals are not just stand-alones, rather, they are embedded in larger systems that affect them in various ways. Changes implemented at the individual level may not last if the system is in opposition, however; if changes are implemented in the larger system, there is a greater likelihood that they will be sustained.

Participant B also indicated that she would like to conduct talks within her community. She, however, identified potential social barriers to doing this: 
There will be a challenge that I will encounter especially because I am still young and I am a woman. There will be difficulties getting more people involved because they will not take me seriously, especially the elders and majority of men in my community.

What stands out is the fact that Participant B clearly felt unequipped to deal with the patriarchy and ageism she identified as potentially inhibiting her work.

While most of the students' responses indicated that they were primarily orientated towards individual-level interventions, some indicated that they were motivated to extend their work beyond individual therapy. I was not, however, convinced that they understood what was actually required to address the wider systemic issues they had been exposed to. For example, how can a psychologist assist a client who is being stigmatised and prejudiced in the health care system-beyond helping her or him cope emotionally? How does the student who recognises how gender dynamics will prevent her from working within her community act to challenge this? Does the student who wishes to collaborate with, and train, community workers in the health care system have the skills to enable her to develop such a partnership?

McArthur (2010, p. 493) contended that a common feature of critical pedagogy is the view that the primary aim of education is the improvement of social justice through change. McArthur (2010) pointed out that advocates of critical pedagogy have been criticised for not bringing about the social and systemic change they aspire towards. He suggested that one of the reasons for this is because such change is "multi-levelled" and "multi-dimensional" (McArthur, 2010, p. 499). Substantial change, therefore, requires the collaboration of individuals, groups, and organisations-and educators cannot risk believing that an isolated educational practice can lead to social change. As Freire argued in an interview on empowerment: "Critical development of ... students is absolutely fundamental for the radical transformation of society. Their curiosity, their critical perception of reality, is fundamental for social transformation but is not enough by itself" (Shor \& Freire, 1987, p. 23). Therefore, while I have presented evidence that body mapping can lead to a critical analysis that orientates future psychologists towards civility (Waghid, 2007), I cannot claim that the workshop and use of a critical pedagogical tool like body mapping in and of itself leads to wider social transformation that meaningfully addresses the social factors that drive the HIV and AIDS epidemic.

I believe that the students' vision for future practice is mediated by their extensive training, from undergraduate through to postgraduate levels, in mainstream psychology. Trainee psychologists have been, for the main part, entrenched in individualistic theories that explain human behaviour, and directed towards individual interventions like psychotherapy (Nelson \& Prilleltensky, 2010). It is not surprising that their aspirations for social change will be limited. In order to equip students to address these kinds of situations, professional psychology training programmes in South Africa need to engage more rigorously with the aims of a social justice approach to counselling. Such an approach emphasises the importance of training students in the areas of social advocacy and activism, outreach and prevention programmes, and public policy (Ratts, Singh, Nassar-McMillan, Butler, \& McCullough, 2016). In addition, they need to teach psychologists in training how to develop collaborative partnerships with various stakeholders to bring about the multi-level and collective action needed to implement changes that will make a meaningful and significant difference to those infected and affected by HIV and AIDS (Campbell, 2004; McArthur, 2010).

\section{Conclusion}

Giroux and Giroux (2006, p. 29) contended that "public education is about more than job preparation or even critical consciousness raising; it is also about imagining different futures and politics as a form of intervention in public life." Students, therefore, need to be taught how to imagine a better world 
and how to intervene to bring about a better world. While body mapping has the potential to develop critical thinking and to orientate future psychologists towards addressing HIV and AIDS through their professional practices, unless they develop the skills to actually bring about the kinds of systemic changes that are needed in the context of HIV and AIDS, the critical pedagogical value of social justiceorientated workshops and exercises like body mapping remain limited.

\section{Acknowledgments}

Thanks to the University Capacity Development Grant (UCDG) for funding.

\section{References}

Bell, A. (2007). Theoretical foundations for social justice education. In M. Adams, A. Bell, D. J. Goodman, \& K. Y. Joshni (Eds.), Teaching for diversity and social justice. New York, USA: Routledge.

Brett-MacLean, P. (2009). Body mapping: Embodying the self living with HIV/AIDS. CMAJ, 180(7), 740741.

Campbell, C. (2004). The role of collective action in the prevention of HIV/AIDS in South Africa. In D. Hook (Ed.), Critical psychology (pp. 10-23). Lansdowne, South Africa: UCT Press.

Fassin, D. (2003). The embodiment of inequality: AIDS as a social condition and the historical experience in South Africa. EMBO reports, 4(special issue), S4-S9.

Freire, P. (1996). Pedagogy of the oppressed. London, UK: Penguin. (Original work published 1970)

Giroux, H. A. (2001). Theory and resistance in education: Towards a pedagogy for the opposition. Westport, USA: Bergin \& Garvey.

Giroux, H. A., \& Giroux, S. S. (2006). Challenging neoliberalism's new world order: The promise of critical pedagogy. Cultural Studies, Critical Methodologies, 6(1), 21-32.

Hackman, H. W. (2005). Five essential components for social justice education. Equity and Excellence in Education, 38, 103-109. doi:10.1080/10665680590935034

Hook, D. (2004). Critical psychology: The basic co-ordinates. In D. Hook (Ed.), Critical psychology (pp. 10-23). Lansdowne, South Africa: UCT Press.

Human Sciences Research Council (HSRC) (2018). The fifth South African national HIV prevalence, incidence, behaviour and communication survey, 2017: HIV impact assessment summary report. Cape Town, RSA: HSRC Press.

Kelly, K., Parker, W., \& Lewis, G. (2001). Reconceptualising behaviour change in the HIV/AIDS context. In C. Stones (Ed.), Socio-political and psychological perspectives on South Africa (pp. 251-276). London, UK: Nova Science.

Kostoulas, A., \& Lammerer, A. (2015). Classroom-based research: Materials created for EIT connect. Graz, Austria: University of Graz.

Lewis, D. (2011). Representing African sexualities. In S. Tamale (Ed.), African sexualities: A reader (pp. 199-216). Cape Town, RSA: Pambazuka Press.

MacGregor, H. N. (2009). Mapping the body: Tracing the personal and the political dimensions of HIV/AIDS in Khayelitsha, South Africa. Anthropology \& Medicine, 16(1), 85-95. doi:10.1080/136484708024226326

MacPhail, C., \& Campbell, C. (2001). "I think condoms are good but, aai, I hate those things": Condom use amongst adolescents and young people in a South African township. Social Science and Medicine, 52(11), 1613-1627. 
McArthur, J. (2010). Achieving social justice within and through higher education: The challenge for critical pedagogy. Teaching in Higher Education, 15(5), 493-504. doi:10.1080/13562517.2010.491906

Morgan, J., \& The Bambanani Women's Group. (2003). Long life: Positive HIV stories. Landsdowne, South Africa: Double Storey Books.

Mpofana, N. (2013). CCMS Freirearian workshop 2013: Documenting the self. SUB texts, 23, 6-7.

Murray, M., Nelson, G., Poland, B, Maticka-Tyndale, E., \& Ferris, L. (2004). Assumptions and values of community health psychology. Journal of Health Psychology, 9(2), 323-333.

Nelson, G., \& Prilleltensky, I. (2010). Community psychology: Journeys in the global context. In G. Nelson \& I. Prilleltensky (Eds.), Community psychology: In pursuit of liberation and well-being (pp. 3-22). Basingstoke, UK: Palgrave Macmillan.

Phatlane, S. N. (2003). Poverty and HIV/AIDS in apartheid South Africa. Social Identities, 9(1), 73-91.

Ratts, M. J., Singh, A. A., Nassar-McMillan, S., Butler, S. K., \& McCullough, J. R. (2016). Multicultural and social justice counseling competencies: Guidelines for the counseling profession. Journal of Multicultural Counseling and Development, 44(1), 28-48.

Rohleder, P. (2016). Othering, blame and shame when working with people living with HIV. Psychoanalytic Psychotherapy, 30(1), 62-78. doi:10.1080/02668734.2015.1107125

Shisana, O., Rehle, T., Simbayi, L.C., Zuma, K., Jooste, S., Zungu, N., . . Onoya, D. (2014) South African national HIV prevalence, incidence and behaviour survey, 2012. Cape Town, South Africa: HSRC.

Shor, I. \& Freire, P. (1987). What is the "dialogical method" of teaching? The Journal of Education, 169(3), 11-31.

Waghid, Y. (2004). Deliberation and citizenship: Closing some of the gaps related to the "Values in Education" initiative in South Africa. South African Journal of Education, 24 (4), 278-283.

Waghid, Y. (2007). University education and critical pedagogy. South African Journal of Higher Education, 21(2), 360-363.

Walker, J. \& Palacios, C. (2016). A pedagogy of emotion in teaching about social movement learning, Teaching in Higher Education, 21(2), 175-190. doi:10.1080/13562517.2015.1136280

Willan, S. (2000). Considering the impact of HIV/AIDS on democratic governance and vice versa. Durban, South Africa: HEARD, University of KwaZulu-Natal.

Wilson, E. (2012). Introduction: Why should teachers do school-based research? In E. Wilson (Ed.), School-based research: A guide for educators (pp. 1-11). Los Angeles, USA: SAGE.

Zembylas, Z. (2015). "Pedagogy of discomfort" and its ethical implications: The tensions of ethical violence in social justice education. Ethics and Education, 10(2), 163-174. doi:10.1080/17449642.2015.1039274 